\title{
Pramlintide, the synthetic analogue of amylin: physiology, pathophysiology, and effects on glycemic control, body weight, and selected biomarkers of vascular risk
}

\section{Byron J Hoogwerf \\ Krupa B Doshi \\ Dima Diab}

Department of Endocrinology, Diabetes and Metabolism, Cleveland Clinic Foundation, Cleveland, USA
Correspondence: Byron J Hoogwerf Desk A-53, 9500 Euclid Ave, Cleveland, $\mathrm{OH}, \mathrm{USA}$

Tel +I 2164448347

Fax +I 216445 I656

Email hoogweb@ccf.org

\begin{abstract}
Pramlintide is a synthetic version of the naturally occurring pancreatic peptide called amylin. Amylin and pramlintide have similar effects on lowering postprandial glucose, lowering postprandial glucagon and delaying gastric emptying. Pramlintide use in type 1 and insulin requiring type 2 diabetes mellitus (DM) is associated with modest reductions in HbA1c often accompanied by weight loss. Limited data show a neutral effect on blood pressure. Small studies suggest small reductions in LDL-cholesterol in type $2 \mathrm{DM}$ and modest reductions in triglycerides in type $1 \mathrm{DM}$. Markers of oxidation are also reduced in conjunction with reductions in postprandial glucose. Nausea is the most common side effect. These data indicate that pramlintide has a role in glycemic control of both type 1 and type 2 DM. Pramlintide use is associated with favorable effects on weight, lipids and other biomarkers for atherosclerotic disease.
\end{abstract}

Keywords: pramlintide, glycemic control, diabetes mellitus

\section{Introduction}

The benefits of glycemic control on reducing the risk for microvascular complications are now quite well established from both observational data sets and intervention trials (DCCT Research Group 1993, 2001; DCCT/EDIC Research Group 2000; UKPDS Research Group 1998a,b). Several factors limit the ability to normalize blood sugar in diabetic patients. These include the inability to target each of the pathophysiological defects associated with hyperglycemia, side effects of medication, contraindications to use of selected medications (eg, renal dysfunction, heart failure), risks for hypoglycemia, and the common association of intensive glycemic control with a risk for weight gain. This article will focus on the use of pramlintide, a synthetic version of amylin (a glucose lowering hormone) and its role in the management of diabetes. Pramlintide targets mainly postprandial glycemic excursion, and as such the effects on mean glycemic control as determined by HbAlc are modest. However, there are very few contraindications, hypoglycemia risk is low, and absence of weight gain (or even weight loss) typifies its use. This article will review the development of pramlintide, its use in diabetes mellitus (DM) as a glycemic control agent, and its effects on body weight as well as current limited data on blood pressure, lipids, and some oxidation biomarkers that are associated with cardiovascular disease risk.

\section{Amylin physiology and pathophysiology}

Amylin is a 37 amino acid polypeptide that is co-secreted in equimolar quantities with insulin from pancreatic $\beta$ cells (Uwaifo and Ratner 2005; Young 2005). Of note is 
the fact that amylin secretion is diminished (or even absent) in patients with types 1 and 2 diabetes (Baron et al 2002). Furthermore, the degree of insulin deficiency generally correlates with the degree of amylin deficiency (Young 2005). Amylin is metabolized by proteolytic degradation in the kidney (Young 2005).

Amylin has glucose-lowering effects in both animals and humans. Uwaifo and Ratner (2005) have summarized the effects (with their corresponding extensive references) as follows: (1) suppression of endogenous glucagon production, especially in the postprandial state; (2) consequent reduction of postprandial hepatic glucose production; (3) reduction in gastric emptying time; (4) centrally mediated induction of satiety; and (5) reduction in postprandial glucose levels.

Because native amylin was characterized as "glue like," somewhat unstable as a compound in solution, modifying amylin to a compound with more manageable physical properties resulted in the development of pramlintide. Pramlintide has similar physiologic effects as native amylin (see Table 1), but could be produced as the stable injectible product now available for clinical use as Symlin ${ }^{\mathrm{TM}}$ (Thompson et al 1998; Vella et al 2002; Kleppinger and Vivian 2003). Physiologic effects of native amylin and the synthetic analogue, pramlintide, include suppression of postprandial glucagon and slowing of gastric emptying. Insulin deficiency and glucagon excess have both been shown to contribute to postprandial glycemic excursion (Shah et al 2000). Thus the effects of pramlintide on postprandial glycemic control appear to be at least partially mediated by restoring appropriate prandial reduction in glucagon (Gedulin et al Young 1997; Fineman et al 1999b, 2002a; Levetan et al 2003; Heptulla et al 2005). It does not appear that this prandial suppression of glucagon by pramlintide impedes the glucagon response to hypoglycemia. Amiel evaluated each of the counter-regulatory hormones triggered by hypoglycemia (catecholamines, growth hormone, cortisol, and glucagon) and found that pramlintide administration did not attenuate the effects of any of them, including glucagon (Amiel et al 2005).

\section{Glycemic control in diabetes mellitus}

\section{Pramlintide use in type I DM}

The preprandial administration of pramlintide as an adjunct to preprandial insulin therapy leads to a substantial reduction in postprandial hyperglycemia (Kolterman et al 1995, 1996; Thompson et al 1997a,b; Nyholm et al 1999; Weyer et al 2001; Weyer et al 2003; Heptulla et al 2005; Hoogwerf 2006) as a result of suppressing postprandial hyperglucagonemia
(Nyholm et al 1999; Weyer et al 2001; Fineman et al 2002b) as well as delaying gastric emptying (Kong et al 1998; Vella et al 2002). Clinical studies have shown that reduction in postprandial glucose excursion translates into significant and sustained reductions in HbA1c (see Table 2) (Fineman et al 1999a; Gottlieb et al 2000; Whitehouse et al 2002; Ratner et al 2004; Edelman et al 2006). In a multicenter study of 480 patients with type $1 \mathrm{DM}$, Whitehouse and colleagues showed that treatment with pramlintide led to a mean reduction in $\mathrm{HbA} 1 \mathrm{c}$ of $0.67 \%$ from baseline to week 13 that was significantly ( $p<0.0001$ ) greater than the placebo reduction $(0.16 \%)$; a significant placebo-corrected treatment difference was sustained through week $52(\mathrm{p}=0.007$ ) (Whitehouse et al 2002). This was not accompanied by an increased overall event rate of severe hypoglycemia. Ratner and colleagues showed that the addition of pramlintide $60 \mu \mathrm{g} 3$ times daily (tid) or 4 times daily (qid) to insulin led to significant reductions in $\mathrm{HbA} 1 \mathrm{c}$ of $0.29 \%(\mathrm{p}<0.011)$ and $0.34 \%(\mathrm{p}<0.001)$ respectively, compared with a $0.04 \%$ reduction in placebo group, over 52 weeks (Ratner et al 2004). In this study, the proportion of pramlintide vs placebo-treated patients who achieved an HbA1c of $<7 \%$ was 3 -fold higher. This was achieved without an increase in concomitant insulin use in the pramlintide-treated group. In a subset of these patients combined with patients from other studies in whom HbA1c values were $<8.0 \%$ at entry, favorable effects on glycemic control were also demonstrated (Ratner et al 2005).

Table I Summary characteristics of amylin and pramlintide

Amylin
37 amino acid compound
Co-secreted with insulin from beta cells
Deficient in type I and type 2 DM
Renal clearance
Physiological effects
I. Suppression of endogenous glucagon production (especially in the
postprandial state)
2. Reduction in postprandial hepatic glucose production
3. Reduction in gastric emptying time
4. Centrally mediated induction of satiety
5. Reduction in postprandial glucose levels
Pramlintide
Synthetic analogue of amylin (3 amino acid substitutions with proline for
native amino acids
Subcutaneous administration
Effects in type I and type 2 DM
I. Reduction in prandial glucose
2. Reduction in HgbAlc
3. Reduction in prandial glucagon
4. Slowed gastric emptying
5. Weight loss


Table 2 Studies of pramlintide use in patients with type I DM

\begin{tabular}{|c|c|c|c|c|c|c|}
\hline Study & Patients (n) & Study design & Duration (weeks) & Pramlintide dose & HbAlc $\Delta(\%)$ & Wt $\Delta(\mathbf{k g})$ \\
\hline (Fineman et al 1999a) & 586 & $\mathrm{DB}, \mathrm{PC}$, multicenter & 26 & $\begin{array}{l}60 \mu \mathrm{g} \text { tid or } \\
90 \mu \mathrm{g} \text { bid-tid } \\
\text { or placebo }\end{array}$ & $\begin{array}{l}-0.2 \text { ( } p=\text { sign.) } \\
-0.1 \text { (NS) } \\
-0.1 \text { (NS) } \\
+0.1\end{array}$ & $\begin{array}{l}-1.6 \\
-0.7 \\
-1.6 \\
+0.3 \\
\text { (NS) }\end{array}$ \\
\hline (Gottlieb 2000) & 479 & $\mathrm{DB}, \mathrm{PC}$, multicenter & 52 & $\begin{array}{l}60 \mu \mathrm{g} \text { tid-qid or } \\
\text { placebo }\end{array}$ & $\begin{array}{l}-0.4 /-0.3 \\
N R \\
(p=\text { sign. })\end{array}$ & $\begin{array}{l}-1.4 /-1.7 \\
N R \\
(p=\text { sign.) }\end{array}$ \\
\hline (Whitehouse 2002) & 480 & $\mathrm{DB}, \mathrm{PC}$, multicenter & 52 & $\begin{array}{l}30-60 \mu \mathrm{g} \text { qid or } \\
\text { placebo }\end{array}$ & $\begin{array}{l}-0.39 \\
-0.12 \\
(p=0.007 I)\end{array}$ & $\begin{array}{l}-0.5^{\mathrm{a}} \\
+1.0^{\mathrm{a}} \\
(\mathrm{p}<0.00 \mathrm{I})\end{array}$ \\
\hline (Ratner et al 2004) & 479 & DB, PC, multicenter & 52 & $\begin{array}{l}60 \mu \mathrm{g} \text { tid-qid or } \\
\text { placebo }\end{array}$ & $\begin{array}{l}-0.29 /-0.34 \\
-0.04 \\
(\mathrm{p}<0.01 \mathrm{I} \text { and } \\
<0.001)\end{array}$ & $\begin{array}{l}-0.4 /-0.4 \\
+0.8 \\
(p<0.027 \\
\text { and }<0.040)\end{array}$ \\
\hline (Edelman et al 2006) & 296 & $\mathrm{DB}, \mathrm{PC}$, multicenter & 29 & $\begin{array}{l}30-60 \mu g \text { tid or } \\
\text { placebo }\end{array}$ & $\begin{array}{l}-0.5 \\
-0.5\end{array}$ & $\begin{array}{l}-1.3 \\
+1.2 \\
(p<0.0001)\end{array}$ \\
\hline
\end{tabular}

aThese data were extrapolated from graphs, because the absolute values were not reported in the test of the published studies.

Note: Fineman 1999, Whitehouse 2002, Ratner 2004 studies - subjects with entry HbAlc between 7.0 and $8.5 \%(n=477)$ are summarized in Ratner et al 2005.

Abbreviations: $\mathrm{DB}$, double-blind; $\mathrm{MC}$, multicenter; $\mathrm{PC}$, placebo-controlled; R, randomized; RCT, randomized control trials.

Several studies have assessed the effect of pramlintide on weight control in patients with type $1 \mathrm{DM}$. In the study reported by Whitehouse, the greater $\mathrm{HbA} 1 \mathrm{c}$ reduction in the pramlintide-treated group was associated with an average weight loss (rather than commonly observed weight gain with improved glycemic control). Weight loss was significant from week 13 onward (Whitehouse et al 2002). Ratner also reported that greater reduction in $\mathrm{HbAl} \mathrm{c}$ with pramlintide was accompanied by a significant reduction in body weight from baseline to week 52 of $0.4 \mathrm{~kg}$ in the $60 \mu \mathrm{g}$ tid $(\mathrm{p}<0.027)$ or qid $(\mathrm{p}<0.040)$ pramlintide treatment groups, compared with a $0.8 \mathrm{~kg}$ gain in body weight in the placebo group (Ratner et al 2004). A 29-week, double-blind, randomized, placebo-controlled study of 296 patients with type $1 \mathrm{DM}$ showed that pramlintide treatment significantly reduced weight (pramlintide $-1.3 \pm 0.30$, placebo $+1.2 \pm 0.30 \mathrm{~kg}$; $\mathrm{p}<0.0001)$ despite equivalent $\mathrm{HbA} 1 \mathrm{c}$ reductions relative to placebo (Edelman et al 2006).

The most commonly reported adverse effects associated with pramlintide use in type $1 \mathrm{DM}$ were nausea, anorexia, and hypoglycemia in these studies. These adverse effects occurred more often during the initiation of therapy and were usually mild to moderate in nature (Weyer et al 2001; Whitehouse et al 2002; Ratner et al 2004, 2005; Ryan et al 2005; Edelman et al 2006; Nogid and Pham 2006). Pramlintide treatment improved patient satisfaction in some studies despite requiring additional injections (Want 2006; Marrero et al 2007).

\section{Pramlintide use in type 2 DM}

In type $2 \mathrm{DM}$ pramlintide has been approved for use as an adjunct to preprandial insulin with or without concurrent metformin or sulfonylurea therapy in patients with sub-optimal glucose control. This approval was based on the ability of pramlintide to improve glucose control when added to insulin therapy and has been supported by both short and long term studies (Ratner et al 2002, 2005; Whitehouse et al 2002; Hollander et al 2003a, 2004; Gottlieb et al 2007) (see Table 3 ). Ratner conducted a multi-centre randomized clinical trial (RCT) of 1 year duration and showed that addition of pramlintide to meal time insulin resulted in a reduction in a mean $\mathrm{HbA} 1 \mathrm{c}$ of $1 \%$ by 13 weeks at the $150 \mu \mathrm{g}$ dose (Ratner et al 2002). This effect was sustained at the end of 1 year with a mean reduction of HbA1c by $0.6 \%$ in both treatment arms $(75 \mu \mathrm{g}, 120 \mu \mathrm{g})$ compared with the placebo arm. Another study in type $2 \mathrm{DM}$ demonstrated a similar sustained reduction in A1c of $0.62 \%$ at the $120 \mu \mathrm{g}$ dose as compared to placebo $(p<0.05)$ (Hollander et al 2003b). In both long-term studies, a significantly greater proportion of patient in the treatment arm were able to achieve a target HbAlc of $<8 \%$. A pooled post-hoc analysis of 2 large RTC of approximately 500 patients showed that treatment of pramlintide with $120 \mu \mathrm{g}$ bid demonstrated a significant placebo-corrected reduction of $\mathrm{HbA} 1 \mathrm{c}$ of $0.41 \%$ at 26 weeks $(p<0.0001)$ (Hollander et al 2004). In a study similar to the analysis in type $1 \mathrm{DM}$ (Ratner et al 2005), Hollander also reported favorable glycemic effects in type $2 \mathrm{DM}$ patients 
Table 3 Studies of pramlintide use in patients with type 2 DM

\begin{tabular}{|c|c|c|c|c|c|c|}
\hline Study & Pat (n) & Study Design & $\begin{array}{l}\text { Duration } \\
\text { (weeks) }\end{array}$ & Pramlintide dose & $\Delta$ HbAlc (\%) & $\Delta$ Weight (kg) \\
\hline (Thompson & 203 & $M C, R, D B, P C$ & 4 & Placebo & -0.27 & -0.04 \\
\hline et al 1998) & & & & $\begin{array}{l}30 \mu \mathrm{g} \text { qid } \\
60 \mu \mathrm{g} \text { tid } \\
60 \mu \mathrm{g} \text { id }\end{array}$ & $\begin{array}{l}-0.53^{*} \\
-0.58^{*} \\
-0.5 \text { I }^{*}\end{array}$ & $\begin{array}{l}-0.36 \\
-0.89 * * \\
-0.72 * *\end{array}$ \\
\hline (Gottlieb & 499 & $M C, D B, P C$ & 26 & Placebo & -0.1 & 0.1 \\
\hline et al 2007) & & & & $\begin{array}{l}90 \mu \mathrm{g} \text { bid } \\
90 \mu \mathrm{g} \text { tid } \\
120 \mu \mathrm{g} \text { bid }\end{array}$ & $\begin{array}{l}-0.3 \\
-0.4 \\
-0.4^{*}\end{array}$ & $\begin{array}{l}-0.8 \\
-1.3 \\
-1.4\end{array}$ \\
\hline (Ratner et al & 538 & $M C, R, D B, P C$ & 52 & Placebo & $-0.2^{c}$ & $1.0^{c}$ \\
\hline 2005) & & & & $\begin{array}{l}30 \mu \mathrm{g} \text { tid } \\
75 \mu \mathrm{g} \text { tid } \\
150 \mu \mathrm{g} \text { td }\end{array}$ & $\begin{array}{l}-0.3^{c} \\
-0.5^{c} \\
-0.6^{*, c}\end{array}$ & $\begin{array}{l}-0.3^{c} \\
-0.4^{* c} \\
-1.2^{* c}\end{array}$ \\
\hline $\begin{array}{l}\text { (Hollander } \\
\text { et al 2003b) }\end{array}$ & 656 & $M C, R, D B, P C$ & 52 & $\begin{array}{l}\text { Placebo } \\
60 \mu \mathrm{g} \text { tid } \\
90 \mu \mathrm{g} \text { bid } \\
120 \mu \mathrm{g} \text { bid }\end{array}$ & $\begin{array}{l}-0.25^{\mathrm{c}} \\
-\mathrm{b} \\
-0.35 \\
-0.62^{*}\end{array}$ & $\begin{array}{l}+0.7 \\
-{ }^{b} \\
-0.5 \\
-1.4^{*}\end{array}$ \\
\hline $\begin{array}{l}\text { (Hollander } \\
\text { et al 2004) }\end{array}$ & 498 & $\begin{array}{l}\text { Post hoc analysis of } 2 \\
R C T^{d}\end{array}$ & 26 & Placebo $120 \mu \mathrm{g}$ bid & $-0.4 I^{* * *}$ & $-1.8 * * *$ \\
\hline
\end{tabular}

asubset of this population with lower HbAlc values also published (Hollander et al 2003a).

bExcluded after efficacy analyses after results from another study (not identified) indicated that this dose was less effective.

'These data were extrapolated from graphs, because the absolute values were not reported in the test of the published studies.

${ }^{\mathrm{d}} \mathrm{Gottlieb}$ et al (1999), Hollander et al (2004).

$*_{p}<0.05 ; *_{p}<0.01$; ***p $<0.0001$.

Abbreviations: DB, double-blind; MC, multicenter; PC, placebo-controlled; R, randomized; RCT, randomized control trials.

who were close to recommended glycemic targets (Hollander et al 2003a). In these studies patients using pramlintide needed proportionally lower doses of total daily insulin. As demonstrated in the studies of type $1 \mathrm{DM}$, pramlintide does not require $\beta$ cell function to exhibit its full glucose lowering effect. Therefore, it is can also be used in a population with advanced type 2 DM who have reduced $\beta$ cell function.

\section{Effect on body weight}

Improvement in glycemic control and associated increase in body weight is well-known (Purnell and Weyer 2003; Hoogwerf 2006). In UKPDS, weight gain was noted to be greater in the intensive policy group compared to the conventional policy group (UKPDS Research Group 1998a,b) and occurred not only with insulin and sulphonylureas but also with metformin. Participants in the conventional policy group also gained weight. The gain occurred in all groups despite patients receiving dietary advice from a dietitian to maintain a near normal weight. In fact the dietary efforts, including recommendation for a calorie- restricted diet, were implemented 3 months prior to randomization and were continued throughout the trial. This implies that dietary modification, albeit very important, is not sufficient to limit weight gain. Weight gain is a well known barrier to the treatment of type
2 DM, especially in patients who are overweight or obese. Such patients may actually avoid achieving glycemic target to prevent accrual of additional pounds. The etiology of weight gain with improved glycemic control is likely to be multi faceted - reduction in glucosuria, increased caloric intake to avoid hypoglycemia, and anabolic effect of insulin on adipose tissue (Purnell and Weyer 2003). It has been estimated that patients gain about $2 \mathrm{~kg}(4.4 \mathrm{lbs})$ for every $1 \%$ reduction in Hba1c (Purnell and Weyer 2003).

The addition of pramlintide to adjuvant insulin causes weight loss in a majority of people. Of note, the initial studies were not designed to be weight loss trials. But a post-hoc analysis involving 2 large studies that included over 240 patients in each arm showed a placebo corrected reduction in body weight of $0.41 \%$ and $1.8 \mathrm{~kg}(\mathrm{p}<0.0001)$ (Hollander et al 2004). Weight loss is moderate in overweight and moderately obese patients and occurs in spite of a reduction in $\mathrm{HbAlc}$. This is in striking contrast to weight gain with intensification of insulin therapy. Weight loss is more pronounced in patients with severe obesity and occurs regardless of whether patients experience nausea, confirming the notion that the weight reduction is not simply a secondary consequence of nausea. Hollander also noted that pramlintide seemed to have somewhat greater weight lowering effect in patients 
concomitantly treated with metformin (placebo-corrected treatment difference at week $26:-2.5 \mathrm{vs} 1.6 \mathrm{~kg}$ in subjects not concomitantly treated with metformin), but the authors advise caution in the interpretation of the results because of the relatively small sample size and the post-hoc nature of the analyses (Hollander et al 2004).

\section{Weight control/loss mechanisms and studies}

The exact mechanism of amylin mediated weight loss remains undefined. In rodents, amylin has been shown to dose dependently reduce food intake and body weight by affecting the size and duration of meals. This mechanism appears to be centrally mediated and is independent of gastric emptying (Lutz et al 1995; Weyer et al 2001; Schmitz et al 2004). High density amylin sites have been identified in the dorsal raphe and nucleus acumbens, two brain regions that control feeding behavior (Weyer et al 2001).

Pramlintide's effect on appetite targets peripheral episodic satiety signals (Halford 2006) and as such is similar to glucagon-like peptide analogues and peptide YY analogues. There is evidence of a satiety effect in both rodents, diabetic and non-diabetic human subjects. Chapman et al studied 16 diabetic and 14 non-diabetic men to determine the effects of pramlintide administration (compared to placebo) on satiety and caloric intake from an available buffet meal (Chapman et al 2005). Pramlintide was associated with earlier satiety and reduced food intake. As noted above Hollander has reported weight loss with pramlintide administration in obese type 2 diabetes patients (Hollander et al 2003a, 2004; Chapman et al 2005). In an observational study, Want reported on glycemic control and weight changes in 27 subjects with type 2 DM followed for several years (Want and Ratner 2006). Subjects whose baseline body mass index (BMI) was $>25 \mathrm{~kg} / \mathrm{m}^{2}$ lost an average of $4 \mathrm{~kg}$.

\section{Biomarkers of cardiovascular disease}

There are only a few studies that have reported on the effects of pramlintide on risk factors known or suspected to be associated with cardiovascular disease. The favorable effects on appetite and weight reduction suggest that there should be consistent effects on blood pressure reduction, dyslipidemia, and inflammatory/oxidation markers. It should be noted that while there is a large body of evidence suggesting that replacement of amylin with pramlintide in patients with diabetes provides significant clinical benefits, more studies are needed to assess the effect of pramlintide on complications of diabetes. What follows has been reported with amylin and/or pramlintide use.

\section{Blood pressure}

Native amylin has been associated with hypertension in 283 hypertensive patients reported by Kailisam et al (2000). These authors concluded that increased concentrations of amylin seen in hypertensive patients might be genetically mediated rather than assuming any causal relationship. In a letter to Diabetologia, Young reported blood pressure results in 507 type 2 diabetic subjects with pramlintide use showing no differences in systolic or diastolic blood pressure in the 3 treatment groups $(30,75$, or $150 \mu \mathrm{g}$ tid) compared to placebo or any change from baseline during 1 year of treatment (Young et al 1999). It does not appear that hypertension has characterized pramlintide use in the RCTs. Neither hypertension nor marked hypotension are common in clinical practice with pramlintide use. At present it does not appear that pramlintide has any significant effect on blood pressure.

\section{Lipids}

Thomson has reported on lipid values in 203 type 2 diabetic subjects treated with placebo and three different doses of pramlintide (30 $\mu \mathrm{g}$ QID; $60 \mu \mathrm{g}$ TID; $60 \mu \mathrm{g}$ QID) over a period of 4 weeks in a randomized, double blind trial (Thompson et al 1998). Median reductions in total cholesterol for the four groups were $0 \mathrm{mg} / \mathrm{dL}, 9 \mathrm{mg} / \mathrm{dL}, 9 \mathrm{mg} / \mathrm{dL}$, and $14 \mathrm{mg} / \mathrm{dL}$ respectively. The median reduction in the three pramlintide treatment groups was statistically different from baseline. Median LDL changes in the $60 \mu \mathrm{g}$ tid and $60 \mu \mathrm{g}$ qid were $8 \mathrm{mg} / \mathrm{dL}$ and $10 \mathrm{mg} / \mathrm{dL}$, respectively. These differences also reached statistical significance. However, mean changes for the treatment groups were not different than placebo although mean percent changes suggest a dose response relationship for total cholesterol, LDL cholesterol, and triglycerides (Figure 1). Levetan studied 16 patients with type $1 \mathrm{DM}$ and showed that after 4 weeks of pramlintide therapy reductions of postprandial glucose excursion by $86 \%$ and glucagon excursion by $87 \%$ were associated with a reduction of triglyceride excursion by $72 \%$ (Levetan et al 2003). Effects of pramlintide on lipids seem modest. Analyses of lipids in subsets of patients who have lost significant amounts of weight have not been published, so it is not clear if these will parallel the observations reported with exenatide (Blonde et al 2006).

\section{Markers of oxidation}

Oxidized lipoproteins, especially oxidized LDL and downstream oxidation products of myeloperoxidase such as 


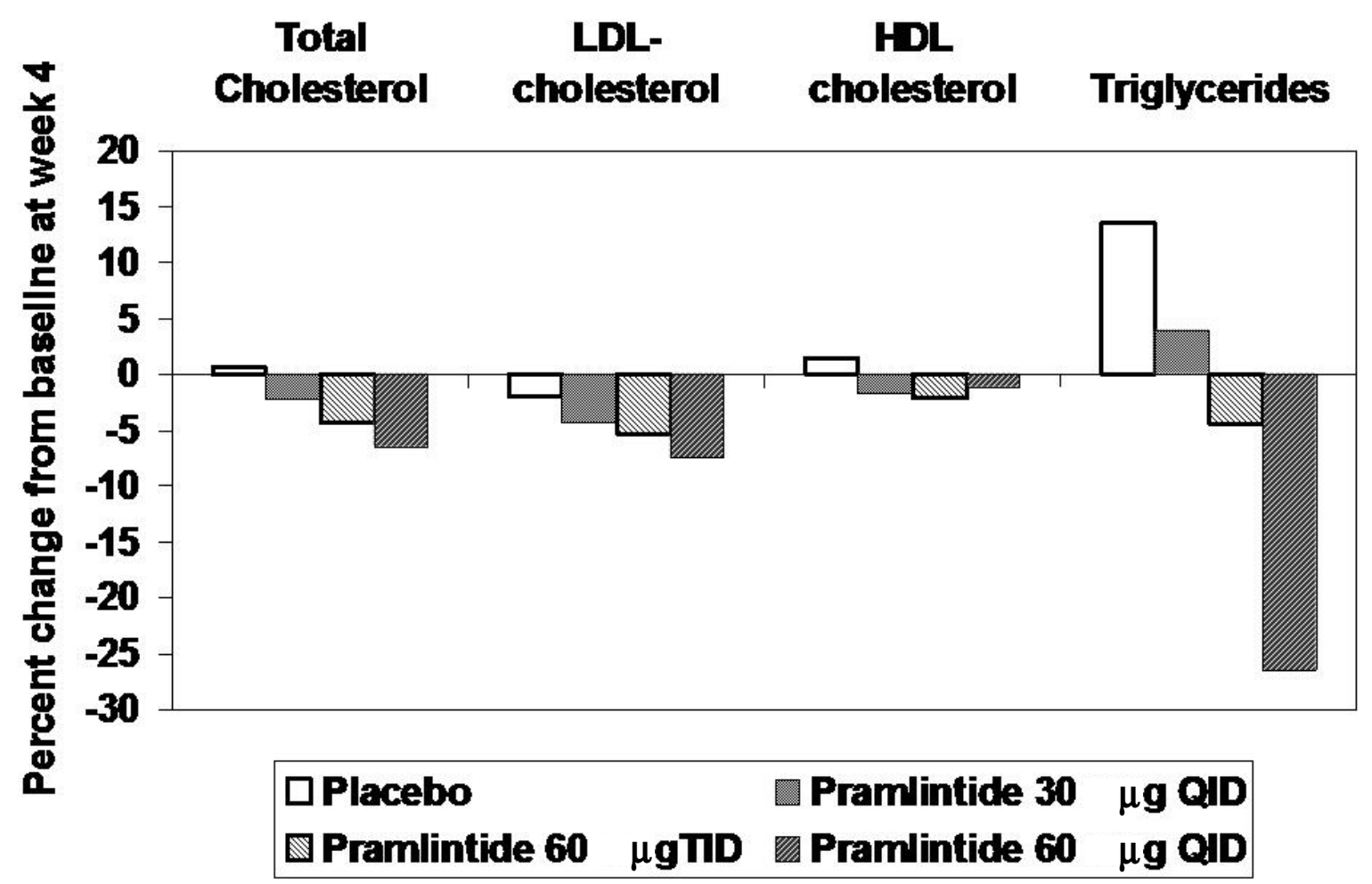

Figure I Mean percent changes in lipid values in 203 type 2 diabetic patients on placebo and 3 different doses of pramlintide for 4 weeks. Derived from Thompson et al (I998).

dinitrotyrosine have been associated with increased risk for cardiovascular disease (Hazen 2000; Shishehbor et al 2003; Nicholls and Hazen 2004, 2005). Oxidation has also been implicated in the pathogenesis of diabetic microvascular complications (Giugliano et al 1996; Ceriello et al 2005, 2007). Pramlintide use has also been associated with a significant reduction in postprandial markers of oxidative stress including significantly reduced postprandial excursions of glucose, nitrotyrosine, and oxidized LDL. Pramlintide also prevented a decline in total radical-trapping antioxidant parameter (using the method reported by Ghiselli called TRAP (Ghiselli et al 1995) as compared with placebo ( $\mathrm{p}<0.03)$. These changes correlated with reduction in postprandial glycemic control.

\section{Practical considerations}

Pramlintide has efficacy when used in conjunction with preprandial insulin therapy in both type 1 and type 2 DM. There is generally a need to reduce insulin requirements when pramlintide is initiated. The reduction in insulin is usually in the range of $20 \%$ to $50 \%$ of preprandial doses (Ryan et al 2005; Want 2006). This adjustment is affected by the individual patient's levels of glycemic control. In patients who are generally well controlled and in whom the use of pramlintide is not only used to reduce prandial glycemic excursion but also to facilitate weight loss, $50 \%$ reductions in preprandial insulin are advisable. In patients with overall suboptimal glycemic control, then continuation of preprandial insulin with only small reductions in dose work well. In any case patients need to be warned about the increased risk for postprandial hypoglycemia (there is a "black box" warning in the package insert) with typical risk occurring for about 3 hours after the meal (Hussar 2005). All patients, especially those with a history of hypoglycemia, need to be instructed to increase the frequency of glucose monitoring to detect hypoglycemia. It is important to note that pramlintide does not impair the glucagon response to hypoglycemia.

Our experience indicates that initiation of pramlintide therapy requires careful instruction even in patients who have taken insulin for extended periods of time. The concept that a $15 \mu \mathrm{g}$ dose corresponds to 2.5 units on an insulin syringe intuitively seems to be an easy concept. The instructions provided with the pramlinitide patient kits review syringe related administration in detail. However, review of dosing administration by a diabetes educator is advisable. Furthermore, many patients have become used to the ease of dosing with insulin delivered via pen. Pramlintide has recently become available in pen delivery devices. Each of these devices has predetermined dosing for pramlintide of $15,30,60$, and $120 \mu \mathrm{g}$. These pens should simplify pramlintide administration. 
Want and Ratner have proposed a dose titration in type 2 diabetes which they report is easier for patients to follow (Want and Ratner 2006). Patients with type $1 \mathrm{DM}$ begin with $12 \mu \mathrm{g}$ ( 2 units on insulin syringe) ac and increase by $6 \mu \mathrm{g}$ (1 unit) every 3-7 days until they reach the target dose of 60 $\mu \mathrm{g}$. Similarly patients with type 2 diabetes begin with $24 \mu \mathrm{g}$ (4 units) and increase by $12 \mu \mathrm{g}$ ( 2 units) until they reach the target dose of $120 \mu \mathrm{g}$ ac. This approach helps to simplify instructions with pramlintide vial usage.

One common question raised by patients is whether pramlintide can be mixed with insulin so that they can give a single injection. Although small short-term studies suggest that mixing with insulin does not affect efficacy (Weyer et al 2005), pramlintide is not approved for use when mixed with insulin and we routinely recommend giving it as a separate injection. The small volume $(0.2 \mathrm{~mL}$ even with the $120 \mu \mathrm{g}$ dose) is not prohibitive for most patients. Pramlintide pens have recently become available which will make dosage instruction and administration easier.

Nausea is common with initiation of therapy. Starting therapy with low dose $(15 \mu \mathrm{g}$ ac in type $1 \mathrm{DM}$ and $30 \mu \mathrm{g}$ ac in type $2 \mathrm{DM}$ ) reduces the risk for nausea. However, our experience indicates that a small percentage of subjects have intolerable nausea even at low doses. This may be a central effect. Nausea is also likely to be more of a problem in patients with gastroparesis, which could be made worse by any agent affecting gastric emptying. However, pramlintide is generally considered to be contraindicated in patients with gastroparesis (Hussar 2005) or in patients who are on other agents known to have effects on gastric emptying such as the alpha glucosidase inhibitors. Except in rare cases, nausea usually remits with continued use. Pramlintide has not been approved for use in pregnancy as safety in pregnancy has not been established.

Pramlintide's use in the immediate future will continue to be as a tool for glycemic control. Future considerations are likely to include monotherapy or as an adjunct to other medications being developed for weight loss. This potential use in weight loss is based on early studies in rodent models (Roth et al 2006). Recently, Amylin reported the following on their web site: “. . . positive results from a 24-week proof-ofconcept study with pramlintide, an analog of human amylin, and recombinant human leptin (r-metHuLeptin; metreleptin) combination treatment in overweight or obese subjects. At study end, pramlintide/metreleptin treatment reduced body weight on average by $12.75 \%$, significantly more than treatment with pramlintide alone $(8.4 \%$; $p<0.001)$." (http://investors.amylin.com/phoenix.zhtml). In spite of these observations, the long-term effects of pramlintide on weight are not known.

\section{Abbreviations}

DM, diabetes mellitus; DB, double blind; LDL, low density lipoprotein; HDL, high density lipoprotein; MC, multicenter; RCT, randomized clinical trial.

\section{References}

Amiel SA, Heller SR, Macdonald IA, et al. 2005. The effect of pramlintide on hormonal, metabolic or symptomatic responses to insulin-induced hypoglycaemia in patients with type 1 diabetes. Diabetes Obes Metab, 7:504-16.

Baron AD, Kim D, Weyer C 2002. Novel peptides under development for the treatment of type 1 and type 2 diabetes mellitus. Curr Drug Targets Immune Endocr Metabol Disord, 2:63-82.

Blonde L, Klein EJ, Han J, et al. 2006. Interim analysis of the effects of exenatide treatment on $\mathrm{A} 1 \mathrm{C}$, weight and cardiovascular risk factors over 82 weeks in 314 overweight patients with type 2 diabetes. Diabetes Obes Metab, 8:436-47.

Ceriello A, Kumar S, Piconi L, et al. 2007. Simultaneous control of hyperglycemia and oxidative stress normalizes endothelial function in type 1 diabetes. Diabetes Care, 30:649-54.

Ceriello A, Piconi L, Quagliaro L, et al. 2005. Effects of pramlintide on postprandial glucose excursions and measures of oxidative stress in patients with type 1 diabetes. Diabetes Care, 28:632-7.

Chapman I, Parker B, Doran S, et al. 2005. Effect of pramlintide on satiety and food intake in obese subjects and subjects with type 2 diabetes. Diabetologia, 48:838-48.

DCCT Research Group. 1993. The effect of intensive treatment of diabetes on the development and progression of long-term complications in insulin-dependent diabetes mellitus. The Diabetes Control and Complications Trial Research Group. N Engl J Med, 329:977-86.

DCCT Research Group. 2001. Influence of intensive diabetes treatment on body weight and composition of adults with type 1 diabetes in the Diabetes Control and Complications Trial. Diabetes Care, 24:1711-21.

DCCT/EDIC Research Group. 2000. Retinopathy and nephropathy in patients with type 1 diabetes four years after a trial of intensive therapy. The Diabetes Control and Complications Trial/Epidemiology of Diabetes Interventions and Complications Research Group. N Engl J Med, 342:381-9.

Edelman S, Garg S, Frias J, et al. 2006. A double-blind, placebo-controlled trial assessing pramlintide treatment in the setting of intensive insulin therapy in type 1 diabetes. Diabetes Care, 29:2189-95.

Fineman M, Bahner A, Gottlieb A, et al. 1999a. Effects of six months of administration of pramlintide as an adjunct to insulin therapy on metabolic control in people wtih type 1 diabetes. Diabetes, 48 (Suppl 1):A113.

Fineman M, Gottlieb A, Bahner A, et al. 1999b. Pramlintide therapy in addition to insulin in type 1 diabetes: effect on metabolic control after 6 months. Diabetologia, 42:A232 (abstract 0872).

Fineman M, Weyer C, Maggs DG, et al. 2002a. The human amylin analog, pramlintide, reduces postprandial hyperglucagonemia in patients with type 2 diabetes mellitus. Horm Metab Res, 34:504-8.

Fineman MS, Koda JE, Shen LZ, et al. 2002b. The human amylin analog, pramlintide, corrects postprandial hyperglucagonemia in patients with type 1 diabetes. Metabolism, 51:636-41.

Gedulin BR, Rink TJ, Young AA. 1997. Dose-response for glucagonostatic effect of amylin in rats. Metabolism, 46:67-70.

Ghiselli A, Serafini M, Maiani G, et al. 1995. A fluorescence-based method for measuring total plasma antioxidant capability. Free Radic Biol Med, 18:29-36.

Giugliano D, Ceriello A, Paolisso G. 1996. Oxidative stress and diabetic vascular complications. Diabetes Care, 19:257-67.

Gottlieb A, Velte M, Fineman M, et al. 2000. Pramlintide as an adjunct to insuln therapy improved glycemic and weight control in people with type 1 diabetes during treatment for 52 weeks. Diabetes, 49(Suppl 1):A109. 
Gottlieb A, Fineman M, Bahner A. 2007. Pramlintide therapy in addition to insulin in type 2 diabetes: effect on metabolic control after 6 months. Diabetologia, 42(Suppl):A232.

Halford JC. 2006. Obesity drugs in clinical development. Curr Opin Investig Drugs, 7:312-18.

Hazen SL. 2000. Oxidation and atherosclerosis. Free Radic Biol Med, 28:1683-4.

Heptulla RA, Rodriguez LM, Bomgaars L, et al. 2005. The role of amylin and glucagon in the dampening of glycemic excursions in children with type 1 diabetes. Diabetes, 54:1100-7.

Hollander P, Maggs DG, Ruggles JA, et al. 2004. Effect of pramlintide on weight in overweight and obese insulin-treated type 2 diabetes patients. Obes Res, 12:661-8.

Hollander P, Ratner R, Fineman M, et al. 2003a. Addition of pramlintide to insulin therapy lowers $\mathrm{HbA1c}$ in conjunction with weight loss in patients with type 2 diabetes approaching glycaemic targets. Diabetes Obes Metab, 5:408-14.

Hollander PA, Levy P, Fineman MS, et al. 2003b. Pramlintide as an adjunct to insulin therapy improves long-term glycemic and weight control in patients with type 2 diabetes: a 1-year randomized controlled trial. Diabetes Care, 26:784-90.

Hoogwerf BJ. 2006. Exenatide and pramlintide: new glucose-lowering agents for treating diabetes mellitus. Cleve Clin J Med, 73:477-84.

Hussar DA. 2005. New drugs: exenatide, pramlintide acetate, and micafungin sodium. J Am Pharm Assoc (2003), 45:524-7.

Kailasam MT, Parmer RJ, Tyrell EA, et al. 2000. Circulating amylin in human essential hypertension: heritability and early increase in individuals at genetic risk. J Hypertens, 18:1611-20.

Kleppinger EL, Vivian EM. 2003. Pramlintide for the treatment of diabetes mellitus. Ann Pharmacother, 37:1082-9.

Kolterman OG, Gottlieb A, Moyses C, et al. 1995. Reduction of postprandial hyperglycemia in subjects with IDDM by intravenous infusion of AC137, a human amylin analogue. Diabetes Care, 18:1179-82.

Kolterman OG, Schwartz S, Corder C, et al. 1996. Effect of 14 days' subcutaneous administration of the human amylin analogue, pramlintide (AC137), on an intravenous insulin challenge and response to a standard liquid meal in patients with IDDM. Diabetologia, 39:492-9.

Kong MF, Stubbs TA, King P, et al. 1998. The effect of single doses of pramlintide on gastric emptying of two meals in men with IDDM. Diabetologia, 41:577-83.

Levetan C, Want LL, Weyer C, et al. 2003. Impact of pramlintide on glucose fluctuations and postprandial glucose, glucagon, and triglyceride excursions among patients with type 1 diabetes intensively treated with insulin pumps. Diabetes Care, 26:1-8.

Lutz TA, Del PE, Scharrer E. 1995. Subdiaphragmatic vagotomy does not influence the anorectic effect of amylin. Peptides, 16:457-62.

Marrero DG, Crean J, Zhang B, et al. 2007. Effect of adjunctive pramlintide treatment on treatment satisfaction in patients with type 1 diabetes. Diabetes Care, 30:210-16.

Nicholls SJ, Hazen SL. 2004. The role of myeloperoxidase in the pathogenesis of coronary artery disease. Jpn J Infect Dis, 57:S21-S22.

Nicholls SJ, Hazen SL. 2005. Myeloperoxidase and cardiovascular disease. Arterioscler Thromb Vasc Biol, 25:1102-11.

Nogid A, Pham DQ. 2006. Adjunctive therapy with pramlintide in patients with type 1 or type 2 diabetes mellitus. Pharmacotherapy, 26:1626-40.

Nyholm B, Orskov L, Hove KY, et al. 1999. The amylin analog pramlintide improves glycemic control and reduces postprandial glucagon concentrations in patien ts with type 1 diabetes mellitus. Metabolism, 48:935-41.

Purnell JQ, Weyer C. 2003. Weight effect of current and experimental drugs for diabetes mellitus: from promotion to alleviation of obesity. Treat Endocrinol, 2:33-47.

Ratner R, Whitehouse F, Fineman MS, et al. 2005. Adjunctive therapy with pramlintide lowers $\mathrm{HbAlc}$ without concomitant weight gain and increased risk of severe hypoglycemia in patients with type 1 diabetes approaching glycemic targets. Exp Clin Endocrinol Diabetes, 113:199-204.
Ratner RE, Dickey R, Fineman M, et al. 2004. Amylin replacement with pramlintide as an adjunct to insulin therapy improves long-term glycaemic and weight control in Type 1 diabetes mellitus: a 1-year, randomized controlled trial. Diabet Med, 21:1204-12.

Ratner RE, Want LL, Fineman MS, et al. 2002. Adjunctive therapy with the amylin analogue pramlintide leads to a combined improvement in glycemic and weight control in insulin-treated subjects with type 2 diabetes. Diabetes Technol Ther, 4:51-61.

Roth JD, Hughes H, Kendall E, et al. 2006. Antiobesity effects of the betacell hormone amylin in diet-induced obese rats: effects on food intake, body weight, composition, energy expenditure, and gene expression. Endocrinology, 147:5855-64.

Ryan GJ, Jobe LJ, Martin R. 2005. Pramlintide in the treatment of type 1 and type 2 diabetes mellitus. Clin Ther, 27:1500-12.

Schmitz O, Brock B, Rungby J. 2004. Amylin agonists: a novel approach in the treatment of diabetes. Diabetes, 53(Suppl 3):S233-S8.

Shah P, Vella A, Basu A, et al. 2000. Lack of suppression of glucagon contributes to postprandial hyperglycemia in subjects with type 2 diabetes mellitus. J Clin Endocrinol Metab, 85:4053-9.

Shishehbor MH, Aviles RJ, Brennan ML, et al. 2003. Association of nitrotyrosine levels with cardiovascular disease and modulation by statin therapy. JAMA, 289:1675-80.

Thompson RG, Pearson L, Kolterman OG. 1997a. Effects of 4 weeks' administration of pramlintide, a human amylin analogue, on glycaemia control in patients with IDDM: effects on plasma glucose profiles and serum fructosamine concentrations. Diabetologia, 40:1278-85.

Thompson RG, Pearson L, Schoenfeld SL, et al. 1998. Pramlintide, a synthetic analog of human amylin, improves the metabolic profile of patients with type 2 diabetes using insulin. The Pramlintide in Type 2 Diabetes Group. Diabetes Care, 21:987-93.

Thompson RG, Peterson J, Gottlieb A, et al. 1997b. Effects of pramlintide, an analog of human amylin, on plasma glucose profiles in patients with IDDM: results of a multicenter trial. Diabetes, 46:632-6.

UKPDS Research Group 1998a. Effect of intensive blood-glucose control with metformin on complications in overweight patients with type 2 diabetes (UKPDS 34). UK Prospective Diabetes Study (UKPDS) Group. Lancet, 352:854-65.

UKPDS Study Group 1998b. Intensive blood-glucose control with sulphonylureas or insulin compared with conventional treatment and risk of complications in patients with type 2 diabetes (UKPDS 33). UK Prospective Diabetes Study (UKPDS) Group. Lancet, 352:837-53.

Uwaifo GI, Ratner RE. 2005. Novel pharmacologic agents for type 2 diabetes. Endocrinol Metab Clin North Am, 34:155-97.

Vella A, Lee JS, Camilleri M, et al. 2002. Effects of pramlintide, an amylin analogue, on gastric emptying in type 1 and 2 diabetes mellitus. Neurogastroenterol Motil, 14:123-31.

Want L. 2006. Use of pramlintide: the patient's perspective. Diabetes Educ, 32(Suppl 3):111S-18S.

Want LL, Ratner RE. 2006. Pramlintide: A new tool in diabetes management. Curr Diab Rep, 6:344-9.

Weyer C, Fineman MS, Strobel S, et al. 2005. Properties of pramlintide and insulin upon mixing. Am J Health Syst Pharm, 62:816-22.

Weyer C, Gottlieb A, Kim DD, et al. 2003. Pramlintide reduces postprandial glucose excursions when added to regular insulin or insulin lispro in subjects with type 1 diabetes: a dose-timing study. Diabetes Care, 26:3074-9.

Weyer C, Maggs DG, Young AA, et al. G. 2001. Amylin replacement with pramlintide as an adjunct to insulin therapy in type 1 and type 2 diabetes mellitus: a physiological approach toward improved metabolic control. Curr Pharm Des, 7:1353-73.

Whitehouse F, Kruger DF, Fineman M, et al. 2002. A randomized study and open-label extension evaluating the long-term efficacy of pramlintide as an adjunct to insulin therapy in type 1 diabetes. Diabetes Care, 25:724-30.

Young A. 2005. Tissue expression and secretion of amylin. Adv Pharmacol, 52:19-45.

Young A, Kolterman O, Hall J. 1999. Amylin innocent in essential hypertension? Diabetologia, 42:1029. 